\title{
Study on water resources and water environment in urban agglomeration
}

\author{
Manli Liu ${ }^{1 *}$, Ying Wang ${ }^{1}$ \\ ${ }^{1}$ School of Management, Tianjin University of Technology, Tianjin 300384, China
}

\begin{abstract}
This study is the result of analysis on the influencing factors of water resources and water environment in Beijing-Tianjin-Hebei urban agglomeration during 2010-2019. Based on the spatial and temporal distribution of water resources, the effective utilization rate and recovery rate of water resources, analysis of groundwater exploitation, reservoir construction, surface water pollution, soil erosion, etc., the overall situation of water resources and water environment in the Beijing-Tianjin-Hebei urban agglomeration is obtained, and the water resources are further effectively controlled to strengthen the security of water environment.
\end{abstract}

\section{Introduction}

In the context of rapid urbanization and the development of urban agglomerations, the problem of water resources caused by strong human activities has become increasingly prominent, which has brought more severe challenges to the environmental protection of urban water resources and the security of water supply. In order to clarify the influencing factors of human activities on the evolution of water resources, scholars at home and abroad have conducted many studies, focusing on the response to human activities such as lake and runoff water quality and quantity changes, and the contribution of climate and human activities to the impact of water resources evolution $^{[1-3]}$. With the deepening of research, the research on the factors affecting the evolution of water resources has formed a series of qualitative and quantitative methods, including the cumulative anomaly method, distributed hydrological model, system dynamics, principal component Analysis ${ }^{[4-7]}$.

As the largest urban agglomeration area in the north and the most competitive support platform in the world, the Beijing-Tianjin-Hebei urban agglomeration has carried the country. $24 \%$ of the population and $11 \%$ of the total economic output, but its regional area is only the national area $2.35 \%$, water resources accounted for $1 \%$ of the total water resources in the country, becoming the most severe water shortage area among all urban agglomerations in China ${ }^{[8]}$. In view of this, from the perspective of research on the impact of strong human activities on the evolution of water resources in the Beijing-Tianjin-Hebei urban agglomeration, the author adopts the DPSIR conceptual framework model to construct an indicator system for the impact of strong human activities on the evolution of water resources in the Beijing-Tianjin-Hebei urban agglomeration, and then uses component analysis method is used to conduct in-depth discussion, in order to clarify the degree of water resources disturbed by strong human activities and the main influencing factors under the background of rapid urban agglomeration, and provide theoretical support for the study of water resources evolution and urban water supply security in the Beijing-Tianjin-Hebei urban agglomeration.

\subsection{Data and methods}

\subsubsection{Overview of the study area}

The Beijing-Tianjin-Hebei urban agglomeration is located in the northern part of the North China Plain, in the Haihe River Basin. Although there are rivers such as the Haihe River and Luanhe River in the area, with the acceleration of urbanization, the population density continues to increase, the secondary and tertiary industries are developing rapidly, and social production The increasin demand for water resources in life has caused serious shortage of water resources in the Beijing-Tianjin-Hebei region $^{[9]}$. In 2016, the regional water resources in the Beijing-Tianjin-Hebei region were $262 * 108 \mathrm{~m}^{3}$, and the per capita water resources were $234.09 \mathrm{~m}^{3}$ per person, accounting for only $9.94 \%$ of the national per capita water resources, while the total regional water consumption was $248.6 * 108 \mathrm{~m}^{3}$, a severe situation of serious overload of water resources utilization has been formed ${ }^{[10]}$. Solving the serious shortage of water resources has become a top priority for the development of the Beijing-Tianjin-Hebei region.

\subsubsection{DPSIR conceptual framework model}

The DPSIR conceptual framework model is a comprehensive improvement of the PSR model and the DSP model. Because of its unique advantages in

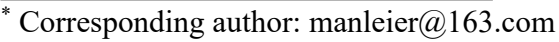


identifying the relationship between economic and social operations and environmental sustainable development, it is widely used in water and soil resource utilization efficiency, regional ecological environmental safety, and soil conservation. Evaluation and decision-making in related fields such as utilization and sustainable agricultural development ${ }^{[11]}$. The DPSIR model identifies the interaction between economic and social development and the environment, and establishes a causal chain of "Driving(D)-Pressure(P)-State(S)-Impact(I)-

Response(R)" between the two, revealing the way in which economic and social development affects the environment and the environment The state's response to human activities can effectively integrate issues between human activities, economic and social development, and resources and the environment.

\subsection{Index system construction}

Table 1 shows the indicator system of the impact of strong human activities on the evolution of water resources constructed in this study.

With the continuous deepening of the Beijing-TianjinHebei integrated development strategy, the effect of population and industrial agglomeration has become more and more obvious. Human production and domestic water extraction activities such as multi-source water diversion, groundwater extraction, industrial water consumption and agricultural water consumption have become an impact on Beijing-Tianjin-Hebei One of the main human activity factors in the evolution of water resources in urban agglomerations; In addition, with the introduction of the "Water Pollution Prevention and Control Action Plan" and the accelerated establishment of the Beijing-Tianjin-Hebei coordinated linkage mechanism, soil erosion protection measures and regional water pollution control have achieved significant results. Among them, the construction of water conservancy facilities, vegetation coverage, sewage discharge and treatment and other regional water environmental protection measures are also another important factor affecting the evolution of water resources in the Beijing-Tianjin-Hebei urban agglomeration. The mutual influence and coupling of various factors have brought great challenges to the identification of the factors affecting the evolution of water resources and the determination of the degree of influence under strong human activities. Therefore, this research is based on the DPSIR conceptual framework model and adopts a "problem-oriented" approach to conduct a systematic and in-depth investigation of the human activity patterns and intensity, economic and social development level, and regional water resources status of the Beijing-Tianjin-Hebei urban agglomeration to clarify the strong human activities, The causal relationship among the various factors of the problem, status, influence and response is based on the analysis of many literatures and drawing on the research results of predecessors ${ }^{[6]}$, while taking into account the scientific, dynamic, systematic, and operability principles of index selection As well as the attributes and levels of the indicators, based on the abovementioned cause analysis and reasonable conversion and processing of indicators, an indicator system for the impact of strong human activities on the evolution of water resources in the Beijing-Tianjin-Hebei urban agglomeration is constructed as shown in Table 1 .

Table 1. Impact index system of water resources evolution

\begin{tabular}{|c|c|c|}
\hline \multicolumn{2}{|c|}{ Criterion layer } & \multirow{2}{*}{ Index layer } \\
\hline Category & factor & \\
\hline \multirow{3}{*}{$\mathrm{D}$} & Population size & $\begin{array}{c}\text { Per capita water resources }\left(\mathrm{D}_{1}\right)= \\
\text { total water resources } / \text { total } \\
\text { population }\end{array}$ \\
\hline & $\begin{array}{l}\text { Economic } \\
\text { growth }\end{array}$ & Gross Regional Product $\left(\mathrm{D}_{2}\right)$ \\
\hline & $\begin{array}{c}\text { Urban } \\
\text { construction } \\
\text { scale }\end{array}$ & Urban construction land $\left(\mathrm{D}_{3}\right)$ \\
\hline \multirow{2}{*}{$\mathrm{P}$} & \multirow{2}{*}{$\begin{array}{l}\text { Resource } \\
\text { consumption } \\
\text { intensity }\end{array}$} & $\begin{array}{l}\text { Water consumption per ten thousand } \\
\text { yuan of industrial output value }\left(\mathrm{P}_{1}\right)\end{array}$ \\
\hline & & $\begin{array}{l}\text { Water consumption per ten thousand } \\
\text { yuan of agricultural output value }\left(\mathrm{P}_{2}\right)\end{array}$ \\
\hline \multirow{2}{*}{$S$} & \multirow{2}{*}{$\begin{array}{l}\text { Water resource } \\
\text { status }\end{array}$} & Groundwater production $\left(\mathrm{S}_{1}\right)$ \\
\hline & & Sewage discharge $\left(\mathrm{S}_{2}\right)$ \\
\hline \multirow{3}{*}{ I } & \multirow{3}{*}{$\begin{array}{l}\text { Social } \\
\text { ecological } \\
\text { environment }\end{array}$} & $\begin{array}{l}\text { The area of cultivated land is } \\
\text { reduced by }\left(\mathrm{I}_{1}\right)\end{array}$ \\
\hline & & The wetland area is $\left(\mathrm{I}_{2}\right)$ \\
\hline & & Forest coverage is $\left(\mathrm{I}_{3}\right)$ \\
\hline \multirow{4}{*}{$\mathrm{R}$} & \multirow{2}{*}{$\begin{array}{l}\text { Water } \\
\text { Conservancy } \\
\text { Construction }\end{array}$} & Diverted $\left(\mathrm{R}_{1}\right)$ \\
\hline & & Total reservoir capacity $\left(\mathrm{R}_{2}\right)$ \\
\hline & $\begin{array}{c}\text { Environmental } \\
\text { protection } \\
\text { measures } \\
\end{array}$ & Soil erosion control area $\left(\mathrm{R}_{3}\right)$ \\
\hline & $\begin{array}{c}\text { Level of } \\
\text { technological } \\
\text { development }\end{array}$ & Wastewater reuse rate $\left(\mathrm{R}_{4}\right)$ \\
\hline
\end{tabular}

\subsection{Data Sources}

The study area is 14 cities above the prefecture level in the Beijing-Tianjin-Hebei urban agglomeration. The original data of the statistical indicators involved are collected from the corresponding data of these 14 cities. The research time range is 2010-2019. The initial data concerning the statistical indicators of economic and social development and water resources are all derived from the China Statistical Yearbook, Beijing Water Resources Bulletin, Tianjin Water Resources Bulletin, and Hebei Water Resources Bulletin; and the ecological environment, water conservancy The initial data of construction-related statistical indicators comes from the "China Environmental Statistics Yearbook"; the regional water diversion data for each year comes from the "China River Sediment Bulletin". The data is optimized and processed with certain calculation rules to form the final statistical index data. 


\section{Results and discussion}

In order to further identify the extent of the impact of strong human activities on the evolution of water resources in the Beijing-Tianjin-Hebei urban agglomeration, principal component analysis was carried out on the basis of the establishment of the impact index system. In SPSS22. 0 The software standardizes the 14 index data in Table 1, and obtains the influence index correlation coefficient matrix (Table 2), factor eigenvalues and variance contribution rate (see Table 3 ), factor loading matrix and factor through dimensionality reduction processing Score matrix (Table 4). Through the analysis of Table 2, we can see that there is a certain correlation between the 14 indicators, so it is suitable for principal component analysis.

four indicators, indicates the second principal component mainly reflects the beijing-tianjin-hebei urban agglomeration for water resources sustainable development of water conservancy construction, environmental protection response measures.

The third principal component only has a strong positive correlation with water resources per capita $\left(\mathrm{D}_{1}\right)$. And groundwater extraction $\left(\mathrm{S}_{1}\right)$, forest coverage rate $\left(\mathrm{I}_{3}\right)$, water diversion $\left(\mathrm{R}_{1}\right)$, indicating that the third principal component mainly represents the impact of population density in the process of continuous urbanization.

Table 2. Correlation coefficient matrix of water resources evolution impact index driven in Beijing-Tianjin-Hebei urban agglomeration

\begin{tabular}{|c|c|c|c|c|c|c|c|c|c|c|c|c|c|c|}
\hline $\begin{array}{c}\text { Correlation } \\
\text { coefficient } \\
\text { matrix }\end{array}$ & $\mathrm{D}_{1}$ & $\mathrm{D}_{2}$ & $\mathrm{D}_{3}$ & $P_{1}$ & $\mathrm{P}_{2}$ & $\mathrm{~S}_{1}$ & $\mathrm{~S}_{2}$ & $\mathrm{I}_{1}$ & $\mathrm{I}_{2}$ & $\mathrm{I}_{3}$ & $\mathrm{R}_{1}$ & $\mathrm{R}_{2}$ & $\mathrm{R}_{3}$ & $\mathrm{R}_{4}$ \\
\hline $\mathrm{D}_{1}$ & 1 & & & & & & & & & & & & & \\
\hline $\mathrm{D}_{2}$ & -0.048 & 1 & & & & & & & & & & & & \\
\hline $\mathrm{D}_{3}$ & 0.091 & 0.989 & 1 & & & & & & & & & & & \\
\hline $\mathrm{P}_{1}$ & -0.091 & -0.827 & -0.860 & 1 & & & & & & & & & & \\
\hline $\mathrm{P}_{2}$ & -0.061 & -0.928 & -0.929 & 0.949 & 1 & & & & & & & & & \\
\hline $\mathrm{S}_{1}$ & 0.031 & -0.955 & -0.954 & 0.725 & 0.813 & 1 & & & & & & & & \\
\hline $\mathrm{S}_{2}$ & -0.013 & 0.97 & 0.962 & -0.89 & -0.982 & -0.883 & 1 & & & & & & & \\
\hline $\mathrm{I}_{1}$ & -0.069 & 0.997 & 0.991 & 0.851 & -0.944 & -0.95 & 0.980 & 1 & & & & & & \\
\hline $\mathrm{I}_{2}$ & 0.330 & -0.87 & -0.842 & 0.608 & 0.751 & 0.865 & -0.808 & -0.865 & 1 & & & & & \\
\hline $\mathrm{I}_{3}$ & 0.200 & 0.806 & 0.839 & -0.875 & -0.903 & -0.721 & 0.892 & 0.839 & -0.658 & 1 & & & & \\
\hline $\mathrm{R}_{1}$ & 0.214 & -0.250 & -0.165 & 0.197 & $-0.02 \mathrm{o}$ & 0.349 & -0.089 & -0.211 & 0.595 & 0.184 & 1 & & & \\
\hline $\mathrm{R}_{2}$ & -0.046 & 0.829 & 0.816 & -0.565 & -0.679 & -0.816 & 0.775 & 0.824 & -0.681 & 0.555 & -0.315 & 1 & & \\
\hline $\mathrm{R}_{3}$ & 0.445 & -0.644 & -0.601 & 0.37 & 0.531 & 0.643 & -0.584 & -0.636 & 0.933 & -0.465 & 0.724 & -0.449 & 1 & \\
\hline $\mathrm{R}_{4}$ & 0.272 & 0.667 & 0.666 & -0.817 & -0.775 & -0.603 & 0.711 & 0.68 & -0.391 & 0.661 & 0.248 & 0.302 & -0.140 & 1 \\
\hline
\end{tabular}

Table 3. Principal component factor eigenvalue and variancecontribution rate

\begin{tabular}{|c|c|c|c|}
\hline $\begin{array}{c}\text { Principal } \\
\text { component } \\
\text { factor }\end{array}$ & Eigenvalue & $\begin{array}{c}\text { Variance } \\
\text { Contribution } \\
\text { Rate /\% }\end{array}$ & $\begin{array}{c}\text { Cumulative variance } \\
\text { contribution rate /\% }\end{array}$ \\
\hline 1 & 9.579 & 68.424 & 68.424 \\
\hline 2 & 2.337 & 16.696 & 85.12 \\
\hline 3 & 1.064 & 7.602 & 92.722 \\
\hline
\end{tabular}

As can be seen from Table 3, the principal component analysis screened out three principal components that affect the evolution of water resources, and their eigenvalues were all greater than 1 , and the cumulative variance contribution rate reached $92.722 \%$, far exceeding the judgment standard (85\%). Therefore, most of the information of the original indicators could be reflected.

Is determined by table 4 shows that the first principal component index have GDP $\left(\mathrm{D}_{2}\right)$, the urban construction land $\left(D_{3}\right)$, the output value of ten thousand yuan of industrial water consumption $\left(\mathrm{P}_{1}\right)$, ten thousand yuan output value of agriculture water consumption $\left(\mathrm{S}_{1}\right)\left(\mathrm{P}_{2}\right)$, ground water and sewage emissions $\left(\mathrm{S}_{2}\right)$, the area decrease $\left(\mathrm{I}_{1}\right)$, wetlands area $\left(\mathrm{I}_{2}\right)$, forest coverage $\left(\mathrm{I}_{3}\right)$, reservoir pool capacity $\left(\mathrm{R}_{2}\right)$, dirty water reuse rate $\left(\mathrm{R}_{4}\right)$, in comparison, The first principal component and regional GDP $\left(\mathrm{D}_{2}\right)$, the urban construction land $\left(\mathrm{D}_{3}\right)$, the cultivated land reducing area $\left(\mathrm{I}_{1}\right)$, wastewater emissions $\left(\mathrm{S}_{2}\right)$ the four index has a strong positive correlation, the three positive contribution rate are respectively the area decrease $\left(I_{1}\right)$, GDP $\left(D_{2}\right)$, the urban construction land $\left(\mathrm{D}_{3}\right)$; And the amount of water consumption per ten thousand yuan of agricultural output 
value $\left(\mathrm{P}_{2}\right)$ and the amount of groundwater extraction $\left(\mathrm{S}_{1}\right)$ have strong negative correlation. And forest coverage $\left(I_{3}\right)$, reservoir pool capacity $\left(\mathrm{R}_{2}\right)$, wastewater reuse rate $\left(\mathrm{R}_{4}\right)$ and ten thousand yuan of industrial production water consumption $\left(\mathrm{P}_{1}\right)$, wetlands area $\left(\mathrm{I}_{2}\right)$ the positive and negative correlation is relatively weak, the three negative contribution respectively, ten thousand yuan output value of agriculture water consumption $\left(\mathrm{S}_{1}\right)\left(\mathrm{P}_{2}\right)$, ground water, wetland area $\left(\mathrm{I}_{2}\right)$, states that the first principal component is the urban land use change and a result of the combined action of the intensity of artificial water withdrawal.

Table 4. Factor loading matrix and factor score matrix

\begin{tabular}{|c|c|c|c|c|c|c|}
\hline \multirow{2}{*}{$\begin{array}{l}\text { Proj } \\
\text {-ect }\end{array}$} & \multicolumn{2}{|c|}{ Compositional load matrix } & \multicolumn{3}{|c|}{$\begin{array}{c}\text { Component score } \\
\text { coefficient matrix }\end{array}$} \\
\cline { 2 - 7 } & 1 & 2 & 3 & 1 & 2 & 3 \\
\hline $\mathrm{D}_{1}$ & -0.115 & 0.531 & 0.801 & -0.012 & 0.227 & 0.753 \\
\hline $\mathrm{D}_{2}$ & 0.99 & -0.015 & 0.108 & 0.103 & -0.006 & 0.101 \\
\hline $\mathrm{D}_{3}$ & 0.986 & 0.035 & 0.031 & 0.103 & 0.015 & 0.029 \\
\hline $\mathrm{P}_{1}$ & -0.872 & -0.375 & 0.2 & -0.091 & -0.016 & 0.187 \\
\hline $\mathrm{P}_{2}$ & -0.955 & -0.226 & 0.081 & -0.1 & -0.097 & 0.076 \\
\hline $\mathrm{S}_{1}$ & -0.939 & 0.106 & -0.2 & -0.098 & 0.045 & -0.188 \\
\hline $\mathrm{S}_{2}$ & 0.981 & 0.127 & 0.017 & 0.102 & 0.054 & 0.016 \\
\hline $\mathrm{I}_{1}$ & 0.996 & 0.012 & 0.063 & 0.104 & 0.005 & 0.059 \\
\hline $\mathrm{I}_{2}$ & -0.882 & 0.449 & 0.02 & -0.092 & 0.192 & 0.019 \\
\hline $\mathrm{I}_{3}$ & 0.863 & 0.255 & -0.34 & 0.09 & 0.109 & -0.32 \\
\hline $\mathrm{R}_{1}$ & -0.21 & 0.891 & -0.347 & -0.022 & 0.381 & -0.326 \\
\hline $\mathrm{R}_{2}$ & 0.789 & -0.146 & 0.259 & 0.082 & -0.062 & 0.243 \\
\hline $\mathrm{R}_{3}$ & -0.67 & 0.662 & 0.109 & -0.07 & 0.283 & 0.102 \\
\hline $\mathrm{R}_{4}$ & 0.685 & 0.561 & 0.068 & 0.071 & 0.24 & 0.064 \\
\hline
\end{tabular}

The second principal component and the per capita water resources quantity $\left(D_{1}\right)$, wetlands area $\left(I_{2}\right)$, the forest coverage rate $\left(\mathrm{I}_{3}\right)$, diverted $\left(\mathrm{R}_{1}\right)$, water loss and soil erosion control area $\left(R_{3}\right)$, wastewater reuse rate $\left(R_{4}\right)$ these seven indicators have relatively strong positive correlation, the three positive contribution respectively been obtained $\left(\mathrm{R}_{1}\right)$, water loss and soil erosion control area $\left(\mathrm{R}_{3}\right)$, wastewater reuse rate $\left(\mathrm{R}_{4}\right)$; Water consumption and industrial output value of ten thousand yuan $(\mathrm{P} 1)$, ten thousand yuan output value of agriculture water consumption $\left(\mathrm{P}_{2}\right)$, reservoir pool capacity $\left(\mathrm{R}_{2}\right)$, GDP $\left(\mathrm{D}_{2}\right)$ has a weak negative correlation between the

\section{Conclusion}

Based on the DPSIR model, an index system of the influence factors of human activities on water resources evolution in the Beijing-Tianjin-Hebei urban agglomeration was established, including 14 indicators. By using principal component analysis method, three principal component factors were obtained, and their cumulative contribution rate was $92.722 \%$. According to the analysis results of principal component factor load matrix and factor score matrix, the three principal components respectively reflect the comprehensive effect of urban land use change and artificial water extraction, response measures such as water conservancy construction and environmental protection, and the degree of population density.

Based on the analysis of the principal component load, it was found that the area of cultivated land decreased and the water consumption per ten thousand yuan of agricultural output value were the decisive indexes of the first principal component, which indicated that the level of agricultural development was an important factor affecting the evolution of water resources in the BeijingTianjin-Hebei urban agglomeration. Water diversion is the second decisive index of the principal component, which indicates that the self-owned water resources of BeijingTianjin-Hebei urban agglomeration are far from meeting the needs of social and economic development and human production and living, and the dependence of external water diversion is increasing day by day. Population size is the only strongly correlated index of the third principal component, indicating that the huge pressure on resources and environment caused by population growth in the Beijing-Tianjin-Hebei urban agglomeration should not be underestimated.

\section{References}

1. E. Pall ,M. Niculae, T. Kiss , C. D. Şandru, M. Spînu, JMM, 62, 11(2013)

2. I. Haddeland, J. Heinke, H.Biemans, S. Eisner, M. Flörke, N. Hanasaki, M. Konzmann, F. Ludwig, Y. Masaki, J. Schewe, Proc Natl Acad Sci, 111, 9(2014)

3. C. Wu, L. Zhou, J. Jin, S. Ning, L. Bai, Sci Totat Environ, 710, 25(2020)

4. Y. Jia, X, Ding, W. Hao, Z. Zhou, Y. Qiu, C. Niu, Water Resour Res, 48, 2(2012)

5. S. Lee, K. Sang, Water, 9, 34(2017)

6. Y. Li, F. Zhang, Z. Han, P. Wang, H. Chen, Z. Zhang, J Earth Sci-China, 26, 06(2014)

7. A. Mecke, I. Lee, J.R. Baker jr., M.M. Banaszak Holl, B.G. Orr, Eur. Phys. J. E 14, 7 (2004)

8. L. Sun, B. Pan, A. Gu, H. Lu, W. Wang, Renew Sust Energ Rev, 93(2018)

9. B. Men, H., Liu,. Water, 10,7(2018)

10. Z, Chen, W. Jiang, W. Wang, D. Yue, B. He, K. Jia, Remote Sens-Basel , 10, 1(2017)

11. M. Y. Ashfaq, M.A. Al-Ghouti, H. Qiblawey, N. Zouari, D. F. Rodrigues, Y. Hu, Environ Prog Sustain, 38, 4(2018) 